\title{
SENI ISLAM DALAM PERSPEKTIF AL FARUQI: Sebuah Komparasi
}

\author{
Yulia Eka Putrie \\ Jurusan Arsitektur Fakultas Sains dan Teknologi UIN Maulana Malik Ibrahim Malang. Jalan Gajayana \\ No.50 Malang, Telp. 0341-551354, e-mail: yuliaeka_p@yahoo.com
}

\section{Abstract}

The perspective of Islamic arts proposed by Ismail Raji al Faruqi in his book Islamic Culture Atlas can be considered as a very comprehensive perspective of esthetics and arts based on Islamic worldview. Al Faruqi's perspective of Islamic arts includes various genres of arts, such as literature, calligraphy, ornamentation, interior design, and music. Therefore, al Faruqi's perspective is expected to be able to use in architecture, especially Islamic architecture. Although al Faruqi classifies architecture as a part of interior design, there are some characteristics of architecture in general different from the interior design characteristics proposed by al Faruqi. Hence, further studies are needed to place al Faruqi's perspective in the context of architecture study. That should be done in order that al Faruqi's perspective can be understood in architecture science. Furthermore, the characteristics are hoped to become one of the parameters in esthetic dimension of architecture objects designed in Islamic framework. Therefore, al Faruqi's perspective of Islamic arts can enrich storage area of Islamic architecture science as the implementation of Islamic worldview.

Key words: Islamic arts, architecture, al Faruqi 


\section{Pendahuluan}

Kajian ini berangkat dari sebuah penjabaran mengenai seni Islam yang dicetuskan oleh Ismail Raji al Faruqi. Di dalam bukunya Atlas Budaya Islam, al Faruqi menyatakan bahwa terdapat enam karakteristik estetis seni Islam, yaitu abstraksi, struktur modular, kombinasi suksesif, repetisi, dinamisme dan kerumitan. Keluasan dan kedalaman dari pandangan al Faruqi ini merupakan salah satu buah dari studi panjang al Faruqi selama karir akademiknya. Kedalaman pandangan ini terlihat dari jangkauan pembahasannya, mulai dari tataran operasional, teoretis, hingga tataran filosofis dari seni Islam. Sementara itu, keluasannya tampak dari kemampuan al Faruqi menarik benang merah dari berbagai bidang seni, seperti seni sastra, kaligrafi, ornamentasi, seni ruang dan seni suara.

Di dalam buku ini pula, al Faruqi menempatkan arsitektur sebagai salah satu bagian di dalam seni ruang. Walaupun demikian, ternyata terdapat perbedaan mendasar antara ruang lingkup seni ruang yang dimaksudkan al Faruqi, dengan ruang lingkup arsitektur yang secara umum dipahami di dalam bidang keilmuan ini. Karena itulah, penempatan perspektif al Faruqi mengenai seni Islam ini akan terlebih dahulu ditempatkan pada konteks pemikiran arsitektur. Kajian ini dilakukan agar masing-masing karakteristik estetis seni Islam al Faruqi ini dapat 'dibaca' dengan kosakata keilmuan arsitektur. Dengan demikian, keenam karakteristik estetis seni Islam dapat dijadikan sebagai salah satu parameter bagi objek-objek arsitektur Islam, terutama dalam dimensi estetisnya. Untuk itu, perspektif al Faruqi mengenai seni Islam akan dikomparasikan dengan konsep-konsep arsitektural yang berkaitan dengan keenam karakteristik yang telah disebutkan di atas. Sebelumnya, dipaparkan terlebih dahulu secara umum mengenai ruang lingkup seni Islam menurut pandangan al Faruqi dan kesejajarannya dengan teori-teori arsitektur yang lain.

\section{Seni Ruang dan Arsitektur dalam Perspektif al Faruqi}

Arsitektur termasuk salah satu bagian dari seni ruang. Al Faruqi 
merumuskan seni ruang ke dalam beberapa kategori berdasarkan ruang lingkupnya masing-masing. Kategori pertama adalah bangun tiga dimensi atau seni patung, yaitu seni yang menghasilkan bentuk-bentuk pejal yang memiliki tiga dimensi. Kategori kedua adalah seni yang memainkan peran 'ekstra ornamentasi'. Karya ini dirancang untuk dipandang dari eksteriornya saja dan tidak memiliki ruang yang dapat dimasuki. Kategori ini selanjutnya disebut sebagai 'unit isi', dengan benda-benda yang berdiri sendiri atau separuh menempel sebagai objeknya, misalnya kran air, pelengkung (arch), jembatan, dan terowongan air (al Faruqi, 1999: 156). Kategori ketiga dari seni ruang adalah karya seni yang menambahkan ruang-ruang interior kepada dimensi-dimensi horisontal dan vertikal, sehingga memberikan kesan kedalaman, volume dan massa. Al Faruqi mengungkapkan, seni inilah yang biasa disebut dengan seni arsitektural (al Faruqi, 1999: 157). Sementara itu, kategori keempat dari seni ruang adalah seni lansekap, termasuk di dalamnya karya-karya hortikultura dan aquakultura. Kategori seni ruang yang terakhir adalah desain perkotaan dan pedesaan, yang melingkupi hubungan antara satu bangunan dengan bangunan lainnya, juga antara bangunan dengan ruang terbuka di sekelilingnya dan dengan kampung, desa, lingkungan atau kota yang ditempati oleh bangunan itu (al Faruqi, 1999: 159). Kategori pertama, yaitu seni patung, karena penggunaan ekspresi naturalistiknya, merupakan kategori seni ruang yang hampir tidak ditemui di dalam perkembangan seni Islam. Karenanya, al Faruqi hanya menyertakan empat kategori selanjutnya di dalam ruang lingkup seni ruang yang lebih khusus, yaitu seni ruang Islam.

Dari pengertian di atas, dapat kita simpulkan bahwa apa yang membedakan arsitektur dengan seni patung dan seni 'unit isi' adalah kualitas spasialnya. Sementara itu, ketiga kategori terakhir, yaitu seni arsitektural, lansekap dan desain perkotaan dan pedesaan ternyata dapat diparalelkan dengan ruang lingkup arsitektur itu sendiri secara umum. Hal ini dinyatakan oleh Christian Norberg-Schultz di dalam bukunya Meaning in Western Architecture, yang mengungkapkan ruang lingkup arsitektur sebagai fenomena konkret yang meliputi lansekap, permukiman, sekaligus 
bangunan 'Architecture is a concrete phenomenon. It comprises landscapes and settlements, building and characterizing articulation...'.

Lebih jauh, dari sudut pandang ilmu arsitektur, dapat disimpulkan bahwa seni ruang merupakan salah satu aspek yang terdapat di dalam ruang lingkup kajiannya. Hal ini didasarkan pada penggunaan istilah seni yang menunjukkan adanya titik berat pada faktor keindahan atau estetika. Vitruvius di dalam bukunya, The Ten Books on Architecture, bahkan memasukkan pengetahuan akan keindahan sebagai salah satu dari tiga pe-ngetahuan dasar yang harus dimiliki oleh seorang arsitek, selain pengetahuan akan kegunaan dan kekokohan (Morgan, 1960: 17). Hal ini mempertegas signifikansi keindahan sebagai salah satu dimensi pokok di dalam arsitektur.

Dari penjelasan ini, dapat disimpulkan bahwa istilah 'seni Islam' dalam pandangan al Faruqi dapat digunakan untuk mempertegas ruang lingkup kajiannya. Istilah 'seni Islam' yang digunakan al Faruqi menunjukkan batasan ruang lingkup kajiannya pada dimensi estetis dari pengejawantahan world view Islam. Karenanya, istilah 'seni ruang Islam' dari al Faruqi dapat diterjemahkan pula sebagai batasan ruang lingkup pada kajian ini. Istilah 'Seni ruang Islam' dalam tulisan ini diterjemahkan sebagai kajian tentang dimensi estetis dalam arsitektur Islam.

\section{Kesejajaran Konsep Seni Islam al Faruqi dengan Konsep-Konsep Arsitektural Lainnya}

Karena karakteristik-karakteristik estetis ini dibahas oleh al Faruqi dalam ruang lingkup seni yang masih sangat luas, maka keenamnya masih harus diuji kesejajarannya dengan konsep-konsep arsitektural lainnya. Dengan begitu, dapat diperoleh simpulan bahwa konsep seni Islam al Faruqi bersifat arsitektural dan dapat dijadikan parameter bagi penilaian terhadap objek arsitektur Islam. Jika dilihat sepintas, maka karakteristik estetis seni Islam di atas memiliki kemiripan dengan karakteristik arsitektur Klasik yang berkembang sebelum revolusi industri. Kemiripan ini terletak pada nilai ornamentasi yang sangat penting di dalam arsitektur Klasik dan seni ruang Islam. Hal ini tidak sejalan dengan paham arsitektur Modern 
yang menganggap ornamentasi sebagai sesuatu yang tidak berguna, bahkan sebuah 'kejahatan' (Gombrich, 1984: 59). Salah satu ungkapan yang sangat terkenal dalam aliran arsitektur ini adalah "ornament is crime", yang melukiskan penolakan tokoh-tokohnya terhadap ornamentasi. Karenanya, arsitektur modern sangat menghindari berbagai bentuk ornamentasi.

Walaupun begitu, jika diteliti secara mendalam, maka akan diperoleh kesimpulan bahwa karakteristik ornamentasi yang terdapat pada kedua aliran arsitektur ini sangat berbeda dalam prinsip-prinsipnya. Salah satu perbedaan yang sangat mencolok adalah penggunaan figur-figur manusia dan hewan yang mendapat porsi yang dominan dan digambarkan secara naturalistik di dalam arsitektur Klasik. Sebaliknya, penggunaan figur-figur ini sangat dihindari dalam ornamentasi arsitektur Islam. "This decoration avoided figural sculpture and classical detailing, the two staples of external architectural ornament in the West" (Hillenbrand, 1994: 8). Selain itu, di dalam arsitektur Klasik selalu terdapat satu klimaks di titik tertentu pada ornamentasinya. Di dalam seni Islam, tidak diperoleh klimaks hanya di satu titik tertentu, dikarenakan kuatnya repetisi dan modulasinya (al Faruqi, 2003: 199-200).

Perbedaan-perbedaan pada level bentuk arsitektural ini tampaknya disebabkan karena terdapat perbedaan yang signifikan di dalam level filosofisnya. Kesamaan pada level filosofis yang dapat ditemui, hanyalah bahwa kedua aliran arsitektur ini dijiwai oleh nilai-nilai religius. Sementara itu, perbedaan keduanya terletak pada adanya perbedaan kandungan nilai-nilai religius yang diterapkan ke dalam bentuk-bentuk arsitektural. Arsitektur Klasik Eropa diwarnai oleh percampuran kepercayaan terhadap dewa-dewa (masa Yunani dan Romawi) dan gereja (masa Romanesque dan Byzantium), sedangkan arsitektur Islam dipengaruhi oleh paham tauhid atau keesaan Allah. Walaupun demikian, dibandingkan dengan teori-teori arsitektur modern, karakteristik seni Islam menurut al Faruqi ini lebih dapat disejajarkan dengan teori-teori arsitektur klasik dalam hal ornamentasi. Hal ini dikarenakan, adanya perhatian yang besar terhadap ornamentasi sebagai salah satu pembentuk estetika suatu objek arsitektur.

Selanjutnya, pandangan al Faruqi mengenai seni Islam ini dapat

el-Harakah, Vol. 11, No.1, Tahun 2009 
pula diparalelkan dengan konsep-konsep perancangan di dalam arsitektur posmodern, antara lain konsep representasi, konsep kompleksitas dan ambiguitas, penghargaan terhadap memori dan sejarah, serta pemanfaatan ornamen dan dekorasi. Hollier dengan konsep representasinya, yang disebut sebagai arsitektur pada dasarnya hanyalah general locus atau framework dari representasi. Arsitektur dapat merepresentasikan sebuah agama, kekuatan politik, peristiwa dan lain-lain. Arsitektur selalu merepresentasikan sesuatu yang lain di luar 'dirinya', yang membedakannya dengan bangunan yang lain (Ikhwanuddin, 2005: 86). Dalam pengertian ini, terdapat kesamaan antara pandangan al Faruqi dan konsep representasi Hollier, yaitu kesepakatan bahwa arsitektur merepresentasikan sesuatu yang lain. Seni Islam di dalam pandangan al Faruqi bukan hadir untuk merepresentasikan dirinya sendiri, melainkan sebagai representasi dari world view Islam. Karenanya, ornamentasi dan modulasi di dalam seluruh cabang seni Islam bahkan dihadirkan untuk menyamarkan material yang merupakan simbol dari keduniawian dan menggiring perhatian ke arah pola infinitif yang merupakan simbol dari makna-makna transenden di dalam Islam.

Sementara itu, konsep kompleksitas dan ambiguitas, dalam pengertiannya yang paling sederhana, dapat disejajarkan dengan konsep kerumitan dan dinamisme dalam karakteristik seni Islam berdasarkan perspektif al Faruqi. Penerapan konsep ambiguitas yang dapat ditemui pada sebagian objek arsitektur Islam, misalnya adalah adanya kesan 'pertentangan' antara tampilan eksterior dan interior bangunan. Bagian eksterior bangunan dirancang secara sederhana dan warna-warna alami, sedangkan bagian interior dirancang dengan tingkat kerumitan yang tinggi dan penggunaan ornamentasi dan dekorasi yang kaya warna. Kenyataan ini menampakkan penerapan konsep pertentangan atau ambiguitas pada arsitektur Islam jika dilihat pada tataran wujud semata. Padahal, hal tersebut sebenarnya mengandung kesatuan makna pada tataran filosofis, yaitu nilai seorang muslim di mata Tuhannya terletak pada kualitas ketakwaan yang ada di dalam dirinya. Jika kompleksitas di dalam arsitektur posmodern merupa-kan perlawanan terhadap simplisitas, maka di dalam arsitektur Islam, kompleksitas 
dan simplisitas digunakan bersamaan untuk mendukung satu makna tertentu yang sesuai dengan world view Islam (Ikhwanuddin, 2005: 90).

Mengenai pandangan terhadap sejarah dan memori, konsep arsitektur posmodern dan konsep seni Islam al Faruqi memiliki kesamaan dalam penghargaan terhadap hal ini. Kesamaan ini dikarenakan keduanya melihat sejarah sebagai gudang perbendaharaan bentuk yang kaya dan bernilai tinggi. Hal ini tidak sejalan dengan paham modernisme di dalam arsitektur. Penyebab dari ditolaknya simbol dan bahasa dekoratif di dalam arsitektur modern, di antaranya adalah karena arsitektur modern menolak tradisi dan sejarah masa lalu (Ikhwanuddin, 2005: 89). Karakteristik dinamisme dalam konsep seni Islam al Faruqi menunjukkan bahwa waktu merupakan faktor yang penting di dalam seluruh seni Islam, termasuk seni ruang. Islam menghargai sejarah sebagai pelajaran bagi generasi selanjutnya. Karenanya, di dalam arsitektur Islam tidak dikenal bentuk-bentuk yang 'ketinggalan zaman' atau usang. Seluruhnya dihargai karena kandungan maknanya yang mengarahkan manusia untuk mengingat tauhid. Sesuai dengan nilai-nilai Islam yang diyakini berlaku sepanjang masa, prinsip-prinsip arsitektur Islam merupakan konsep yang dapat diterapkan di setiap masa dan zaman.

Seperti arsitektur klasik, kesejajaran perspektif al Faruqi mengenai seni Islam dengan konsep-konsep arsitektur posmodern dapat pula ditemukan dalam pandangan terhadap penggunaan ornamen dan dekorasi. Seperti arsitektur Islam, arsitektur posmodern juga menerima kehadiran ornamen dan dekorasi. Hal ini disepakati oleh Jencks, Klotz, Kurokawa dan Venturi (Ikhwanuddin, 2005: 94). Walaupun begitu, sebagian metode untuk menghasilkan ornamen dan dekorasi, yaitu metode desain pleasure dan enjoyment, menjadikan tujuan dihasilkannya ornamen dan dekorasi di dalam sebuah arsitektur posmodern hanya sebagai 'permainan' tanpa keharusan untuk dikaitkan dengan fungsi-fungsi tertentu (Ikhwanuddin, 2005: 94). Sebaliknya, di dalam arsitektur Islam, setiap bentuk yang hadir harus memiliki makna dan mengandung nilai-nilai kebenaran dan kebaikan. Ornamentasi bukanlah sesuatu yang ditambahkan secara superfisial pada suatu karya yang telah selesai, untuk sekadar menghias karya ini tanpa ada 
artinya. Ia juga bukan sarana untuk memuaskan selera orang-orang yang mencari kenikmatan semata (al Faruqi, 2003: 412). Dalam hal ini, tampak bahwa kehadiran bentuk-bentuk fisik yang serupa ternyata dapat menjadi tidak sejalan pada tataran filosofisnya.

Dari uraian panjang di atas, dapat disimpulkan bahwa perspektif al Faruqi mengenai seni Islam memiliki kesetaraan dengan konsep-konsep arsitektural lainnya, walaupun kesetaraan ini bukan berarti keduanya selalu mengandung kesesuaian. Pada tataran operasional, teoretis dan tataran filosofis, terdapat kesamaan-kesamaan dan perbedaan-perbedaan, atau bahkan pertentangan-pertentangan, antara pandangan al Faruqi dengan konsep-konsep lainnya di dalam arsitektur. Dengan demikian, kajian dapat dilanjutkan pada penguraian secara lebih rinci mengenai konteks arsitektural dari masing-masing karakteristik estetis seni Islam menurut al Faruqi, sehingga dapat dijadikan sebagai salah satu parameter bagi dimensi estetis objek arsitektur Islam.

\section{Abstraksi}

Dalam ruang lingkup arsitektur, menurut al Faruqi, penerapan abstraksi yang paling mudah dipahami terdapat pada ornamentasi ba-ngunan. Polapola figural dan gambar-gambar yang naturalistis jarang digunakan pada ornamen-ornamen bangunan. Walaupun gambar figural dan alam banyak digunakan, namun gambar-gambar itu terwujud melalui teknik denaturalisasi dan modifikasi. Teknik ini menjadikan gambar itu lebih berperan sebagai penolak naturalisme daripada sebagai gambaran sejati fenomena alam yang sebenarnya (al Faruqi, 2003: 443).

Dalam pandangan masyarakat umum, ornamen hanya dipahami sebagai 'some knick-knack on the mantel-piece', artinya sebagai bagian tambahan yang menghiasi suatu benda atau karya (Gombrich, 1984: 20). Di dalam istilah arsitektural, ornamen merupakan detil dekoratif yang digunakan untuk menghiasi bagian dari bangunan atau perabot ruang dalam. Sebagai sebuah tambahan, ornamen seringkali dianggap tidak fungsional, bahkan sempat dianggap sebagai sebuah 'kejahatan' oleh Adolf Loos de- ngan 
slogannya 'ornament is crime' (Gombrich, 1984: 59). Walaupun demikian, argumen Loos yang pernah menandai berkembangnya arsitektur modern yang miskin ornamentasi ini pada akhirnya meredup seiring de-ngan berkembangnya berbagai pemikiran baru di dalam arsitektur. Salah satu alasan yang menyebabkan hal itu adalah tipisnya perbedaan antara ornamen dan struktur pada beberapa kasus, misalnya pointed arch dan flying buttress pada arsitektur gotik yang selain bersifat ornamental, ternyata juga dibutuhkan secara struktural (Gombrich, 1984: 164). Ornamen ternyata juga memiliki kegunaan praktis sebagai skala pembanding, penanda area tertentu, dan sebagainya. Ornamen juga dapat mempengaruhi persepsi pengamat terhadap suasana ruang. Menurut al Faruqi, ornamen memiliki fungsi menggiring pengamat kepada suasana kontemplatif akan kebesaran Allah SWT.

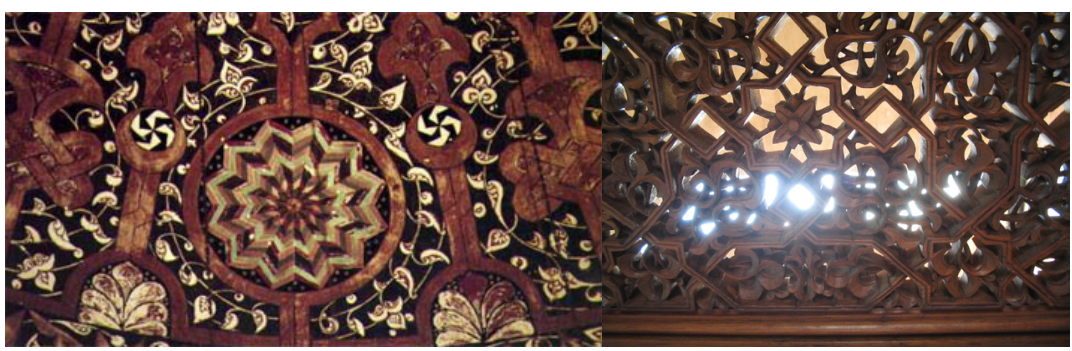

Gambar 1. Abstraksi Pola Dedaunan dan Sulur Tanaman pada Ornamentasi Bangunan (Sumber: Dokumentasi Pribadi).

Selain ornamentasi, metode abstraksi yang lain juga dikembangkan pada arsitektur, desain lansekap dan rancangan kota. Dalam penerapannya di arsitektur, abstraksi dapat dibagi menjadi beberapa kategori, yaitu pelapis, transfigurasi material, transfigurasi struktur, transfigurasi penutup, dan transfigurasi fungsi (al Faruqi, 2003: 443). Transfigurasi dalam hal ini dimaknai sebagai perubahan bentuk atau tampilan objek oleh ornamentasi tanpa mengubah substansinya. Transfigurasi juga bermakna sebagai perubahan bentuk yang tidak semata-mata perubahan, namun merupakan perubahan yang membawa kemuliaan atau spiritualisasi (al Faruqi, 2003: 413).

Salah satu kategori abstraksi dalam konteks arsitektural, transfigurasi penutup, merupakan teknik abstraksi dengan menitikberatkan pada 
peniadaan kesan solid pada bangunan yang meminimalkan kesan keterbatasan ruang (al Faruqi, 2003: 446). Transfigurasi penutup meniadakan secara visual antagonisme atau pertentangan antara manusia de-ngan lingkungan tempatnya tinggal dan bergerak (al Faruqi, 2003: 446). Dengan demikian, terdapat kesinambungan dan keseimbangan hubungan antara alam dan manusia, seperti yang dianjurkan di dalam Islam.

Kategori lain dari konsep abstraksi dalam ruang lingkup arsitektur adalah transfigurasi atau ambiguitas fungsi. Inti dari transfigurasi fungsi adalah, sebuah ruangan atau bangunan tidak dibatasi untuk satu penggunaan saja. Kebutuhan publik maupun privat dapat dipenuhi oleh satu ruangan pada waktu yang berbeda dalam sehari. Begitu pula aktivitas-aktivitas religius yang tidak terisolasi dari aktivitas-aktivitas profan. Terjadi pembauran konstan antara aktivitas religius dan tuntutan duniawi (al Faruqi, 2003: 450). Hal ini berkaitan erat dengan konsep ibadah di dalam Islam yang memandang setiap sendi kehidupan manusia bernilai ibadah berdasarkan niatnya. Pemanfaatan bersama ruang-ruang publik untuk masjid dan sekolah atau pasar, merupakan salah satu contoh penerapan konsep transfigurasi struktur dalam ruang lingkup arsitektur.

\section{Struktur Modular}

Al Faruqi menyatakan bahwa karya seni Islam diciptakan dari banyak bagian atau modul yang digabung untuk melahirkan desain yang lebih besar. Masing-masing modul merupakan entitas yang memberikan batas klimaks dan kesempurnaan yang dapat dipandang sebagai unit ekspresif yang indah (al Faruqi, 2003: 457). Dalam penerapannya di arsitektur, bangunan selalu menghimpun entitas modular yang lebih kecil. Bangunan seringkali merupakan perpaduan unit-unit halaman. Tiap unit terbuka ini bertindak sebagai pusat yang dikelilingi oleh ruangan-ruangan tambahan.

Salah satu modul dalam arsitektur adalah module of dimension yang dapat digunakan pada keseluruhan bangunan. Modul dimensi ini tidaklah harus berupa sebuah ukuran yang kecil dan abstrak, misalnya satu inci, melainkan dapat pula berupa ukuran-ukuran yang lain, seperti dengan 
satuan kaki (feet) atau sebuah elemen konstruksi, seperti ketebalan dinding atau diameter kolom. Secara umum, modul memang diartikan sebagai 'the measurement that architects use to determine the proportions of a structure, for example the diameter of a column' (Meiss, 1997: 62).

Selain modul dimensional seperti yang disebutkan oleh Von Meiss, berdasarkan pernyataan al Faruqi di atas, modul dapat pula berupa struktur dan bentuk tertentu yang merupakan entitas terkecil dalam rancangan yang dapat dikembangkan, dimodifikasi dan dikombinasikan satu sama lain. Dari penjelasan di atas, struktur modular di dalam konteks arsitektural berdasarkan konsep al Faruqi mengandung pengertian modul sebagai unit rancangan terkecil yang memiliki potensi untuk dikombinasikan dan dikembangkan menjadi sebuah kualitas infinitif.
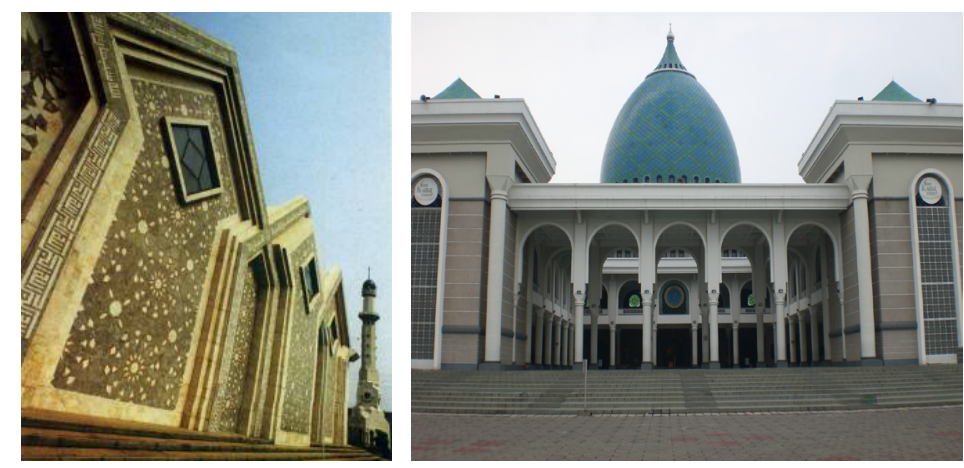

Gambar 2. Penerapan Struktur Modular dalam Arsitektur Masjid (Sumber: Dokumentasi Pribadi).

\section{Kombinasi Suksesif}

Di dalam seni Islam pola infinitif dari suara, gambar dan gerak menunjukkan kombinasi berurutan modul-modul dasar dan pengulangannya. Dengan cara ini, terbentuk kombinasi aditif yang lebih besar, yang mencirikan identitas dan statusnya sendiri. Kombinasi suksesif yang lebih besar dalam karya seni Islam sama sekali tidak menghancurkan identitas dan karakter unit-unit kecil yang membentuknya. Sebaliknya, kombinasi lebih besar seperti itu bahkan dapat diulang, divariasi dan digabung dengan entitas yang 
lebih kecil atau lebih besar lainnya untuk membentuk kombinasi yang jauh lebih kompleks. Dengan demikian, pola infinitif mempunyai banyak pusat perhatian estetis, banyak 'pandangan' yang dapat dianggap sebagai kombinasi berurutan modul, entitas atau motif yang lebih kecil. Tak ada desain yang mempunyai satu titik pangkal estetis atau perkembangan progresif ke titik fokus puncak atau konklusif. Desain ini justru memiliki pusat perhatian atau fokus yang tak ada habisnya, dan mode persepsi internal yang menafikan awal atau akhir yang konklusif (al Faruqi, 2003: 200).

Dalam ruang lingkup arsitektur, modul-modul seringkali digabungkan untuk membentuk kombinasi yang lebih besar pada sejumlah tingkatan. Misalnya, modul ruangan disambung dengan modul taman atau dengan modul bangunan lain yang berdampingan. Tiap-tiap bagian mempertahankan identitasnya sebagai unit mandiri seraya membentuk bagian identitas yang lebih besar ketika bergabung dengan modul serupa atau berbeda di sekitarnya. Lihat Gambar 3 (al Faruqi, 2003: 458).

Konsep kombinasi suksesif dalam konteks arsitektural berkaitan erat dengan artikulasi dan kontinuitas. "Buildings are the volumetric combination of a large number of elements. They are joined together in larger unit which, in turn, modulate the relationships between parts and the whole... In general, we can distinguish two methods of composition of the object: articulation and continuity" (Von Meiss, 1997: 80). Dari pernyataan Von Meiss ini, dapat diketahui bahwa terdapat dua metode dalam mengomposisikan objek, yaitu artikulasi dan kontinuitas. Artikulasi antar elemen mengaksentuasi otonomi bagian-bagian. Artikulasi memperkuat peran tertentu dari elemen-elemen yang berbeda. Artikulasi dapat dihasilkan dari permainan yang simultan dari material, elemen arsitektural, dan sebagainya. Sebaliknya, kontinuitas antar elemen mengurangi otonomi bagian-bagiannya. Kontinuitas mencerminkan elemen terbesar dari keseluruhan objek (Von Meiss, 1997: 80). 


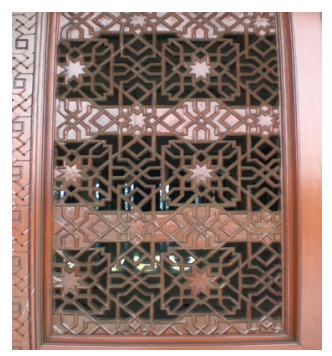

Gambar 3. Dekorasi Pintu Masjid yang Merupakan Kombinasi Banyak Modul Dasar (Sumber: Dokumentasi Pribadi).

Berdasarkan penjelasan al Faruqi di atas, dapat diketahui bahwa kombinasi suksesif yang bertujuan memunculkan kesan infinitif pada objek arsitektur dapat diraih terutama melalui kontinuitas elemen-elemennya. Namun begitu, kenyataan bahwa tiap-tiap bagian memiliki identitas dan karakter tersendiri, seperti yang disebutkan al Faruqi sebelumnya, menyiratkan bahwa artikulasi juga memiliki peran penting dalam kombinasi suksesif ini. Artikulasi pada tiap-tiap elemen atau modul terkecil bisa jadi dibutuhkan agar pengamat tidak mengalami kebosanan akibat kontinuitas yang tinggi. Pengamat dibawa untuk menelusuri 'ketakterbatasan' yang terkandung pada masing-masing modul dengan adanya artikulasi pada masing-masing modul itu. Tanpa artikulasi, pandangan pengamat tidak akan mampu 'digiring' untuk menyadari adanya kualitas infinitif dari masing-masing modul dan kombinasi antar beberapa modul itu. Dengan demikian, dalam konteks arsitektural dapat disimpulkan bahwa konsep kombinasi suksesif yang bertujuan memunculkan kualitas infinitif dapat diperoleh melalui kontinuitas antar modul, sekaligus artikulasi pada masing-masing modulnya.

\section{Repetisi}

Karakteristik keempat dari seni Islam al Faruqi, adalah repetisi tingkat tinggi. Motif, modul struktural dan kombinasi suksesif mengalami pengulangan yang berlanjut secara ad infinitum dan menghasilkan kesan infinitif (al Faruqi, 2003: 200). Unit-unit itu diulangi, baik dalam bentuk yang identik maupun beragam dalam struktur ruang aditif. 
Repetisi dalam bentuk irama, baik dalam musik maupun arsitektur, merupakan prinsip komposisi yang paling sederhana yang cenderung untuk memberikan kesan koheren (keterhubungan). Seluruh bentuk repetisi dapat merupakan hasil dari penambahan atau pembagian dari keseluruhan, atau dapat pula merupakan sebuah urut-urutan tanpa identifikasi yang jelas akan bentuk keseluruhannya (Von Meiss, 1997: 32).

Repetisi dalam skala arsitektur dan urban design, seringkali mengambil bentuk yang kedua karena ketiadaan awal dan akhir yang jelas. Senada dengan hal ini, al Faruqi menyatakan repetisi pada objek arsitektur dapat terjadi mulai dari unit internal bangunan dan taman, hingga kombinasi beberapa struktur yang membentuk kompleks bangunan (al Faruqi, 2003: 460). Repetisi pada skala ini merupakan sebuah urut-urutan kesamaan atau kemiripan dari sebagian bentuk arsitektural yang diamati tanpa berhubungan dengan persepsi objek arsitektur secara keseluruhan (Von Meiss, 1997: 32). Walaupun demikian, repetisi juga dapat terjadi dalam bentuk tatanan simetris yang merupakan penafikan terhadap partikularisme bagian-bagiannya (al Faruqi, 2003: 460). Hal ini menunjukkan bahwa, selain dapat diamati secara parsial pada bagian-bagiannya, repetisi juga dapat diamati pada objek arsitektur sebagai satu kesatuan bentuk.

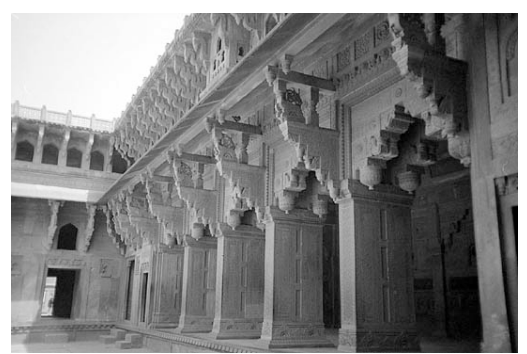

Gambar 4. Repetisi pada Elemen-Elemen Arsitektural (Sumber: Google Image).

\section{Dinamisme}

Seni Islam bersifat dinamis, yaitu desain yang harus dinikmati dalam kurun waktu tertentu. Seni visual dalam budaya Islam, meski berhubungan dengan unsur ruang, tidak dapat dinikmati kecuali melalui waktu. Pola 
infinitif tak dapat dipahami dalam sekilas pandang, dalam sekejap, dengan sekali memandang beragam bagiannya. Pola ini justru menarik mata dan pikiran melalui serangkaian pandangan atau persepsi yang harus dipahami berturut-turut (al Faruqi, 2003: 201).

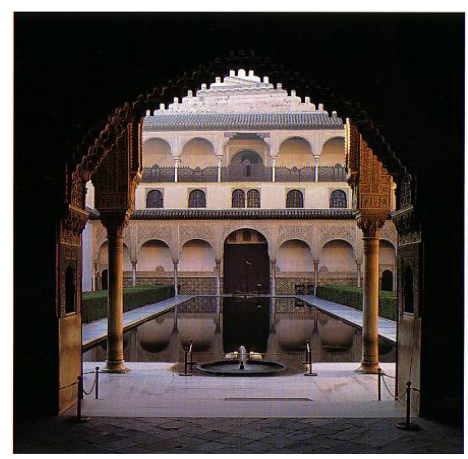

Gambar 5. Sikuen-Sikuen dalam Objek Arsitektur yang Menghasilkan Kesan Dinamis (Sumber: Google Image).

Dalam ruang lingkup arsitektur, pemahaman dan apresiasi terhadap suatu objek arsitektur harus diperoleh melalui penjelajahan unit-unitnya. Kesan atau pemandangan total tidak diperoleh dari kejauhan. Objek arsitektur harus dialami secara dinamis, bukan dalam momen waktu tunggal yang statis. Ia harus dipahami melalui apresiasi sikuensial dari bagian-bagiannya (al Faruqi, 2003: 461).

Waktu merupakan salah satu 'modifying element' dari arsitektur. Dibutuhkan waktu yang cukup banyak untuk mempersepsi arsitektur. Ketika seseorang mengalami arsitektur dalam keberadaan fisiknya, terdapat banyak tahap dalam proses mengalami itu. Hal ini lebih terasa pada objekobjek arsitektur yang processional, misalnya kuil, katedral, dan sebagainya (Unwin, 1997: 35). Walaupun demikian, Unwin juga menyatakan bahwa terdapat pula beberapa objek arsitektur yang dapat dialami sebagai suatu keseluruhan pada satu waktu (Unwin, 1997: 19).

Dari paparan Unwin dapat disimpulkan bahwa waktu merupakan salah satu elemen yang penting bagi arsitektur. Hal ini disepakati pula oleh al Faruqi dalam konsep dinamisme di atas. Kekhususan dari konsep ini terletak pada kualitas infinitif yang dimunculkan dalam pengalaman 
seseorang akan arsitektur. Karenanya, karakteristik dinamisme dalam seni Islam, al Faruqi dikhususkan pada pengalaman arsitektural yang menghasilkan kualitas infinitif.

\section{Kerumitan}

Detail yang rumit, merupakan karakteristik keenam yang mencirikan seni Islam. Kerumitan meningkatkan kemampuan pola atau arabesque untuk menarik perhatian orang yang memandangnya dan mengupayakan konsentrasi pada entitas struktural yang ditampakkannya. Hanya dengan keragaman unsur-unsur internal dan semakin rumitnya goresan serta kombinasinya, maka dinamisme dan momentum pola tak terbatas dapat diwujudkan (al Faruqi, 2003: 202).

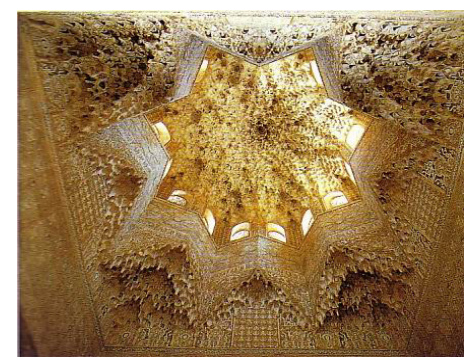

Gambar 6. Kerumitan dalam Detail Interior Ruang Atap Alhambra (Sumber: Google Image).

Dalam ruang lingkup arsitektur, kerumitan kombinasi unit ruang dan massa merupakan kerumitan yang sebanding dengan kerumitan yang terdapat pada dekorasi dua dan tiga dimensional. Selain melalui dekorasi, kerumitan juga dapat dicapai melalui kompleksitas struktural dari objek-objek arsitektur (al Faruqi, 2003: 461-462). Konsep kompleksitas atau kerumitan dalam arsitektur dapat didefinisikan sebagai lawan dari kesederhanaan, dan pada akhirnya lawan dari sesuatu yang jelas dan elementer. Elemen-elemen dikelompokkan dengan cara tertentu hingga menghadirkan lebih dari satu interpretasi kepada para pengamatnya, itulah yang disebut kompleksitas (Von Meiss, 1997: 4546). Metode lain yang juga dapat menghasilkan kompleksitas adalah dengan penyimpangan dari norma yang dapat dihasilkan dari perbedaan dari sebuah simetri yang telah ditetapkan, atau bahkan dari sebuah anomali dari pola-pola 
yang biasa, dapat pula distorsi dari sebuah figur yang telah dikenal (Von Meiss, 1997: 46). Dengan demikian, dalam konteks arsitektural penerapan kerumitan dapat diketahui baik pada dekorasi maupun strukturnya, dengan mengamati keragaman-keragaman, penyimpangan-penyimpangan dan perbedaan-perbedaan pada elemen-elemen arsitektur, seperti dipaparkan di atas.

\section{Simpulan}

Dari paparan di atas, dapat disimpulkan bahwa perspektif al Faruqi mengenai seni Islam ternyata memiliki kesejajaran dengan konsep-konsep yang ada dalam ranah keilmuan arsitektur. Paparan al Faruqi mengenai karakteristik-karakteristik seni Islam itu juga dapat diletakkan pada konteks arsitektural, sehingga dapat dibaca dengan kosakata keilmuan arsitektur. Dalam kerangka pikir keilmuan arsitektur, perspektif al Faruqi mengenai seni Islam dapat didefinisikan sebagai konsep karakteristik estetis arsitektur Islam. Dengan demikian, keberadaannya dapat memperkaya khasanah keilmuan arsitektur, terutama dalam ruang lingkup dimensi estetis arsitektur Islam. Tentu saja, dimensi estetis ini tidak dapat berdiri sendiri. Dimensi estetis di dalam arsitektur Islam harus menyatu dengan dimensi-dimensi lainnya, terutama dimensi kebenaran dan kebaikan, seperti halnya dalam pandangan Islam, keindahan itu sendiri bukanlah semata-mata keindahan pada tataran fisik, melainkan merupakan manifestasi dari kebenaran dan kebaikan yang terkandung di dalam world view Islam secara keseluruhan.

\section{Daftar Pustaka}

Al Faruqi, Ismail Raji. 1999. Seni Tauhid: Esensi dan Ekspresi Estetika Islam. Yogyakarta: Yayasan Bentang Budaya.

Al Faruqi, Ismail R. dan al Faruqi, Lois Lamya. 2003. Atlas Budaya Islam, Menjelajah Khazanah Peradaban Gemilang. Terjemahan oleh Ilyas Hasan. Bandung: Mizan.

Gombrich, EH. 1984. The Sense of Order, A Study in the Psychology of Decorative 
Art. New York: Cornell University Press.

Hillenbrand, Robert. 1994. Islamic Architecture: Form, Function and Meaning. New York: Columbia University Press.

Ikhwanuddin. 2005. Menggali Pemikiran Posmodernisme dalam Arsitektur. Yogyakarta: UGM Press.

Von Meiss, Pierre. 1997. Elements of Architecture, from Form to Place. London: E \& FN Spon.

Morgan, Morris Hicky. 1960. Vitruvius the Ten Books on Architecture. New York: Dover Publication.

Unwin, Simon. 1997. Analysing Architecture. New York: Routledge. 